九州大学学術情報リポジトリ

Kyushu University Institutional Repository

\title{
Land Holding Pattern and Efficiency of Agricultural Production in Nepal : A case study in the eastern hill of Nepal
}

Lama, Ngima Gyalgen

Laboratory of Farm management, Division of International Agricultural Resource Economics and Business Administration, Department of Agricultural and Resource Economics, Graduate School of Bioresources and Bioenvironmental Sciences, Kyushu University

Tsuj i, Masao

Laboratory of Farm management, Department of Agricultural and Resource Economics, Graduate School of Bioresources and Bioenvironmental Sciences, Kyushu University

https://doi.org/10.5109/24384

出版情報: 九州大学大学院農学研究院紀要. 45 (1)，pp.349-364，2000-11. Kyushu University バージョン：

権利関係 : 


\title{
Land Holding Pattern and Efficiency of Agricultural Production in Nepal - A case study in the eastern hill of Nepal -
}

\author{
Ngima Gyalgen Lama* and Tsuji Masao \\ Laboratory of Farm Management, Department of Agricultural and Resource Fconomics, \\ Graduate School of Bioresources and Bioenvironmental Sciences, \\ Kyushu University, Fukuoka 812-8581, Japan \\ (Received July 31, 2000 and accepted August 18, 2000)
}

\begin{abstract}
This study was carried out to identify the land holding pattern and process of land acquisition among the farm households of different food availability status in the eastern hill of Nepal. Analysis on the relationship between the land size and agricultural production, land type, land use ratio, fertilizer use, productivity, family size, employment pattern and cash form non-farm source are made and discussed. In depth analysis of the production environment of households with different land size but obtaining similar cash value of production are carried out and associated factors are presented. The survey result shows an extremely unequal distribution of land among the household categories, indicating a declining trend of land holding from the food surplus to the food deficit households. Positive relation was found between the land size and the annual gross cash value of agricultural production. However, negative relation found between the land size and productivity of maize and millet; both upland and major hill crops, provides a critical issues to be face in terms of poverty eradication and maintaining food security in the hill of Nepal. Interestingly, positive relation was found between the fertilizer use and productivity of maize and wheat.
\end{abstract}

\section{INTRODUCTION}

Nepal being predominantly an agricultural country and agriculture being the backbone of Nepalese economy, increase agriculture production is important to meet the domestic food demand and to increase the farm household income (APROSC 1995). Agriculture growth is important, because eighty one percent of the country labor force depend on it for employment (MOF 2000). Consequently, improvement in the agriculture sector has remained a priority in the country's national development plans.

Agricultural production and productivity depends on the environment in which farmer works and this is composed of physio-climatic, socio-cultural and structural factors. Of the three, structural environment is the most important for policy formulation, which is composed of tenurial structure, superstructure and infrastructure in agriculture (Tiwari 1990).

Farm land is a fundamental productive means of agricultural production. Nepal with only 17 percent of its total area under cultivated land, farm land is a scarce resource. Furthermore, the distribution of this scarce resource remained very much skewed even after land reform carried out in 1964 (NESAC 1993) and issues of land ownership often

\footnotetext{
* Laboratory of farm Management, Division of International Agricultural Resource Economics and Business Administration, Department of Agricultural and Resource Economics, Graduate School of Bioresources and Bioenvironmental Sciences, Kyushu University, Fukuoka 812-8581, JAPAN.
} 
becomes a political slogan. As tenurial structure and land size distribution is interdependent, one of the policies issues surrounding improvement in the agriculture sector therefore, concerns the concentration of land holding (Dahal 1993). It is often argued that a high degree of concentration of land holding tends to deter productivity and diminish the potential for improvement by marginalizing the interest of a large proportion of the farmers. Therefore, it is further argued that greater equity in the distribution of land is essential if the country is to increase agricultural productivity and improve the agricultural sector as a whole.

This background provides the necessity context for important question that need to be investigated: 1) what is the status of land holding or how unequal is the distribution of land holding among the farm households; 2) What is the relationship between the land size and agricultural production; and 3) whether the farm households having different size of land have the different value of production or a same one. Information on these aspects are important for planning policy and approaches for agricultural development programme.

The objectives of the study are: 1) to identify the land holding pattern among the farm households and process of land acquisition; 2) to identify the relationship between the land size and agricultural production; and 3) to analyze the production environment of the households having different land size but obtaining same or more production.

The data used for this paper is based on the study carried out in Belhara Village Development Committee (Photo 1) of the Dhankuta district in the eastern hill of Nepal (Figure 1) during the middle of 1998. A farmer categorization list prepared on the basis

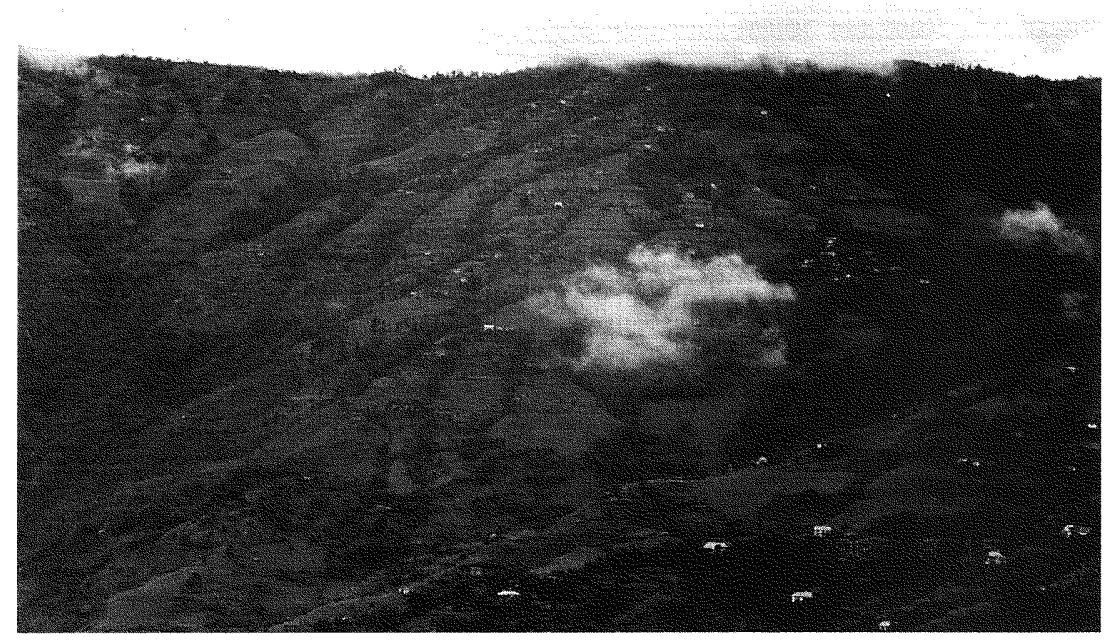

Photo 1. A general view of the study area 


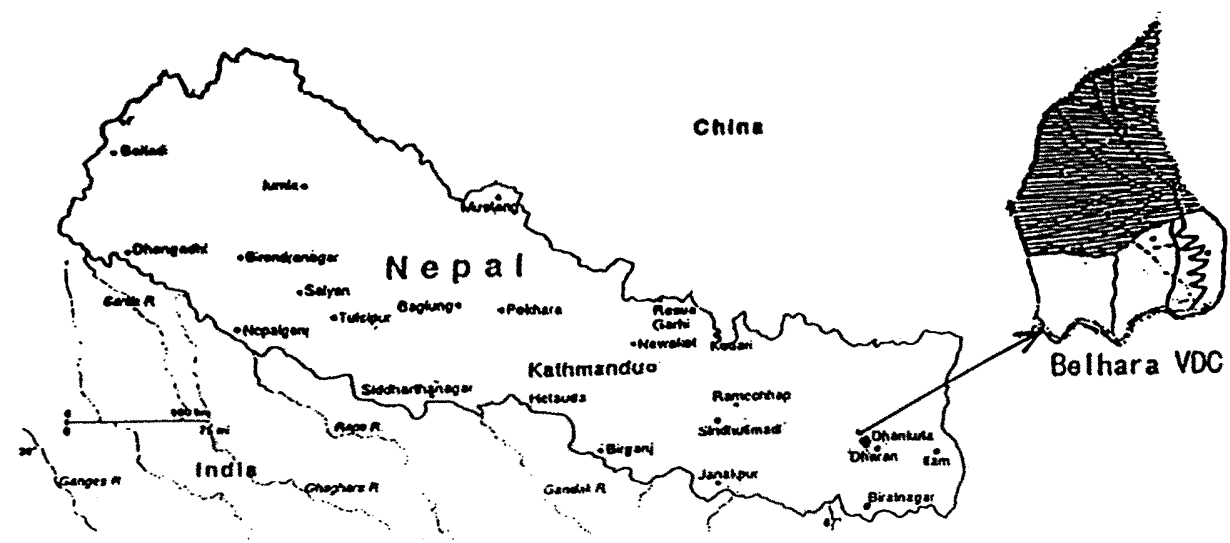

Fig. 1. Location of the study area

of food availability status ${ }^{1}$ by Pakhribas Agricultural Center (PAC), a research center of eastern Nepal was taken for selecting the farm households. A total of 28 farm households (5 households from category A, 7 from category B and C and 9 from category D) were selected by multistage stratified random sampling. Interview was taken with the head of the household, and the interview period varied from one and half hours to three hours depending on the household socio-economic status. Locally adopted units of measurement were converted to metric system during data processing. Correlation analysis is used to find the relationship between land size and production, land use ratio, productivity and household structure. A detailed comparison of two farm households having different land size but obtaining similar production was carried out.

\section{LAND HOLDING PATTERN}

\section{Land type}

Four types of land were recorded from survey. They are: low land (khet), upland (bari), uncultivated land (Pakho, khar bari, baan) and garden (bagaicha). Low land (Photo 2) is irrigated land where rice is the major crop grown, whereas upland is rain-fed land and maize is the dominant crop. The low land is considered superior than the upland in the hill of Nepal; as it has partial or full irrigation facility necessary for rice cultivation, better terrace management causing low run off rate of soil and fertilizer, soil are considered more fertile, and accordingly land prices are considerably higher than the upland. Since, rice is the most prestigious grain crop in Nepal, the farmer measure their wealth according to the amount and type of low land they own (Carson 1992).

\footnotetext{
'The food availability status from own farm sources was the major parameter adapted by the farmers in classifying the farm households during the farmer categorization exercise carried out by PAC (Joshi et al. 1993). The common definition used for classification of farm household are as follows;

Category A: Food surplus household

Category B: Food balance household

Category D: Food sufficient for less than 6 months

Category C: Food sufficient for more than half year but less than a year
} 


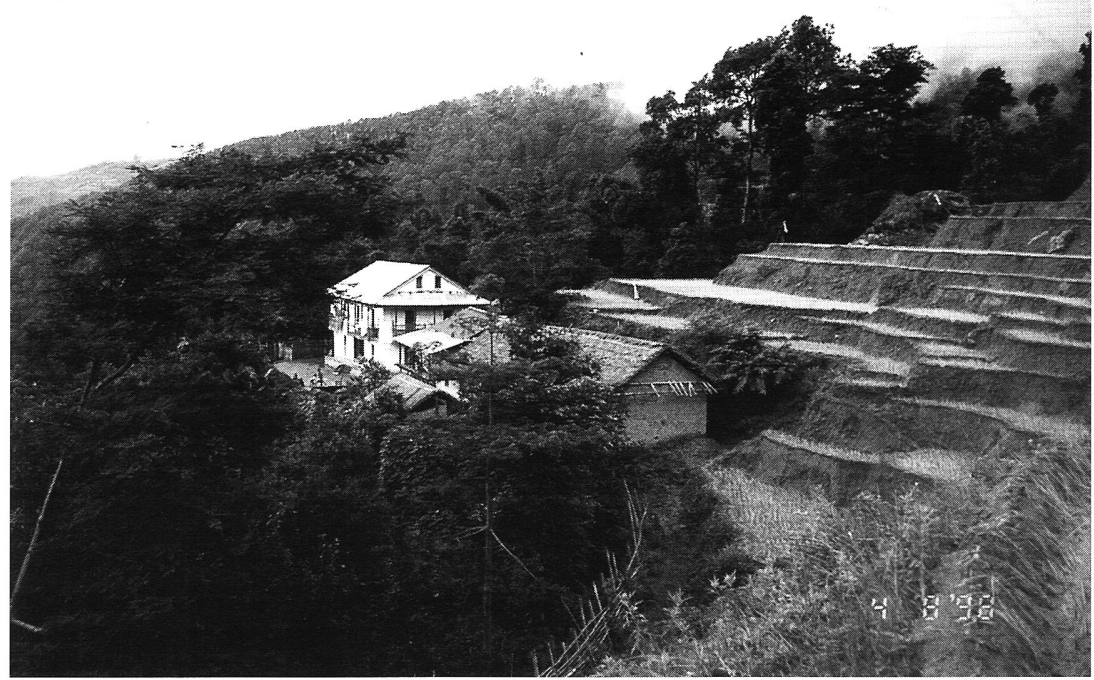

Photo 2. Low land (khet) in the hill of Nepal: better terrace management and availability of irrigation where rice is the major crop grown

Table 1. Average land holding by household categories in hectare

\begin{tabular}{cccccc}
\hline $\begin{array}{l}\text { Household } \\
\text { Category }\end{array}$ & Lowland (ha) & Upland (ha) & $\begin{array}{c}\text { Fruit garden } \\
\text { (ha) }\end{array}$ & $\begin{array}{c}\text { Uncultivated } \\
\text { Land (ha) }\end{array}$ & Total \\
\hline A & $3.16(100)$ & $2.12(100)$ & $0.51(60)$ & $0.96(100)$ & 6.75 \\
B & $1.12(100)$ & $1.19(100)$ & - & $0.31(43)$ & 2.62 \\
C & $0.38(86)$ & $0.69(100)$ & - & $0.12(28)$ & 1.18 \\
D & $0.11(33)$ & $0.49(100)$ & - & $0.07(66)$ & 0.67 \\
\hline
\end{tabular}

Figure in parenthesis indicates percentage of households of respective categories that owned each type of land

Data source: Field survey, 1998

Uncultivated land are those which are not suitable for growing field crop due to over slope and this area is utilized by growing fodder and fuel trees. Garden refers to the area of land covered by fruit trees and cardamom.

\section{Average land holding}

Land holding is a symbol of wealth, prestige and power in Nepal. However, the result shows that there is unequal distribution of land across the categories (Table 1). Average land holding of the category A is six time higher than category D and more than five times than that of category C. Within the land type, category A have more of the low land than the upland whereas only three household out of 9 surveyed households from category D posses a low land with comparatively smaller size. Since the low land is important from the point of view of rice production, a source of staple food in Nepal, the majority of 
Table 2. Distribution of household categories with respect to land size (\%)

\begin{tabular}{crcrr}
\hline \multirow{2}{*}{ Land size (ha) } & \multicolumn{5}{c}{ Household category } \\
\cline { 2 - 5 } & A & B & C & D \\
\hline 0.5 & - & - & - & 44 \\
$0.5-1$ & - & - & 57 & 56 \\
$1-2$ & - & 43 & 43 & - \\
$2-3$ & - & 28 & - & - \\
$3-4$ & 20 & 28 & - & - \\
$>4$ & 80 & - & - & 100 \\
Total & 100 & 100 & 100 & 8 \\
\% share of total land & 53 & 27 & 12 & 9.1 \\
People /ha of arable land & 1.74 & 2.72 & 5.20 & \\
\hline
\end{tabular}

Data source: Field survey, 1998

category D households were in the disadvantage position to it.

\section{Concentration of land holding}

The survey result on the distribution of households with respect to the land size and categories and people per hectare of arable land is presented in the Table 2 . It was found that, of the total land available, 53 percent of land area is held by category A followed by 27 percent by $\mathrm{B}$ (Table 2 ). The category $\mathrm{C}$ and $\mathrm{D}$ were left with only remaining portion of 12 and 8 percent of land respectively. Consequently, 44 percent of the category $\mathrm{D}$ households holds a land area of less than half hactare. In other hand, majority of the category A households posses more than 4 hectares of land. This shows that the land holding tends to decline from the surplus category to the deficit category households. Ironically, 9.1 people of category D household have to depend on 1 hectare of land for their subsistence giving an enough issue for poverty alleviation.

\section{Process of land ownership}

In Nepal, it is the tradition and also there is provision by law for a parental property to be inherited by their sons. As son separate from their parents, the farm is divided equally between the sons which is termed as "aansa" in Nepali, and this process is being followed from generation to generation. In other hand, there is also legal provision for land buying

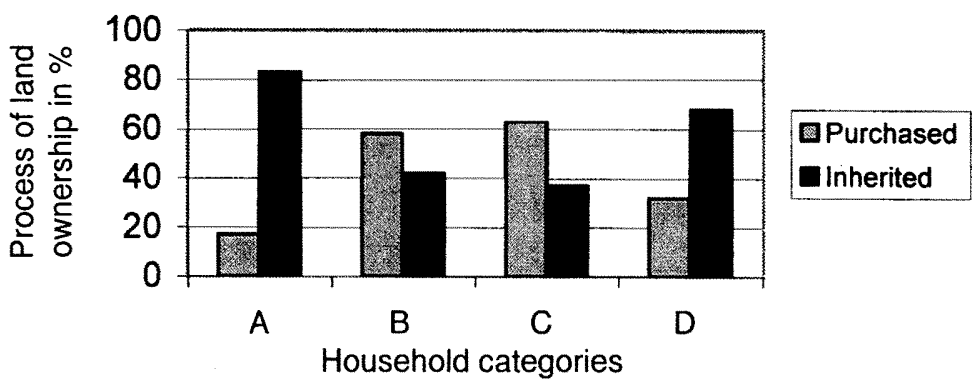

Fig. 2. Process of land ownership (in \%) 
and selling. Land ownership can be obtained legally after paying the settled price to the landowner and completing the necessary official documents.

The survey result also identified two process of land acquisition ie. (1) land received (inherited land) from the parents and (2) land acquire by purchase. The result shows that of the total land owned by category A, 83 percent of the land were acquired from their parental source as inherited land, and the purchase land includes only 17 percent (Figure 2). Similarly, 68 percent of the land belonging to category D were inherited land. It was found that the category $\mathrm{C}(63 \%)$ and $\mathrm{B}(58 \%)$ have more of their holding acquired from purchasing. The reason for more $\mathrm{C}$ category involved in purchasing the land is contributed by the fact that 43 percent of the household were migrated from the other place and settled in the study area.

\section{Economic factor influencing size of land purchase}

The size of land purchased was again found different accordingly with the category. Category A purchased a bigger size of land ranging from 2.3 to 3 hactare followed by category $\mathrm{B}$ that ranges from 0.65 to 3.8 hectares. The size of the land purchase by the category $\mathrm{C}$ and $\mathrm{D}$ were comparatively smaller than $\mathrm{A}$ and $\mathrm{B}$ which ranges from minimum of 0.25 and 0.1 hactare to maximum of 1 and 0.7 hactare respectively. Although, 63 percent of the land belonging to the category $\mathrm{C}$ is from purchase, the percent share from the total purchased land is only 22 percent. Category B have a larger share of 45 percent followed by category A (25\%) and least was by category $D$ which was only 8 percent. The difference in the size of land purchased was due to the purchasing ability of the households that depend directly on the resources held by the household which was different among the categories and even within the categories.

The survey result indicates that irrespective of the household category, one fourth of the land were purchased from the absentee landlord. More than half of the landowner those who sold the land were migrated to the terai (southern part of Nepal) where the infrastructure is more developed than hills and agriculture is more productive.

\section{Average cultivated land holding}

Due to greater land to labor ratio, $80 \%$ of the A category households were found to be renting out their paddy land with land area ranging from half to four hectares. Renting in land was more prevalent in category $\mathrm{C}$ and $\mathrm{D}$ households. It was found that nearly half of the households from category $\mathrm{C}$ and $\mathrm{D}$ respectively have acquired land ranging from 0.15 to 1 hectares from the various sources; majority of them form the absentee land lord,

Table 3. Average cultivated land (ha)

\begin{tabular}{ccccc}
\hline Household category & Low land & Upland & Fruit garden & Total \\
\hline A & $1.82(100)$ & $2.12(100)$ & $0.51(60)$ & 4.45 \\
B & $1.12(100)$ & $1.19(100)$ & - & 2.31 \\
C & $0.49(86)$ & $0.81(100)$ & - & 1.30 \\
D & $0.33(44)$ & $0.73(100)$ & - & 1.06 \\
\hline
\end{tabular}

Figure in parenthesis indicates percentage of households of respective categories that owned each land type

Data source: Field survey, 1998 
landlord and relatives. However, still the average cultivated land of category C and D is found to be smaller compare to the category A and B (Table 3). The result shows that the average cultivated land of category A ( $4.45 \mathrm{ha})$ is nearly four times more than that of C (1.3 ha) and D (1.06 ha). Similarly cultivated land of category B (2.31) was nearly double than that of $\mathrm{C}$ and $\mathrm{D}$. As the land is one of the important factor of agricultural production, differences in the holding of land for cultivation has an important role influencing the household food availability.

\section{Land tenure}

Two types of contractual arrangement of land were recorded: they are 1) share cropping and 2) renting land on fixed cash basis. Share cropping system was predominant in the paddy land in which the production is equally shared between the landlord and tenants. While the later system was common in the upland, in which the land is rented to the tenants by taking a fixed amount of money. It was found that the tenants had been paying an amount ranging from 1000-1400 Nepali Rupees per hactare of rain-fed upland.

\section{LAND SIZE AND PRODUCTION EFFICIENCY}

The above discussion on the land holding pattern across the household categories indicated an existence of unequal distribution of land. This part presents the relationship between the land size and agricultural production.

\section{The relationship between the land size and gross cash value of agricultural production}

The term gross cash value of agricultural production includes both the cash received from sale of livestock, livestock product, fruit and vegetables as well as the cash value (based on prevailing local price) of the cereal, pulses and potatoes production of the household in a year at the same place and time. The land size is the area of land under cultivation by farm households.

Gross cash value is taken with the consideration that it represents the result of the household production environments over a year and reflects the farm management ability of farm households in obtaining agricultural production through the proper use of resources it holds.

The result shows a positive correlation ( 0.82$)$ between the land size and gross cash value of agricultural production. This implies that larger land holding tends to have

Table 4. Land size (ha) and gross cash value of agricultural production (Rs)

\begin{tabular}{lcc}
\hline Description & Land size (ha) & $\begin{array}{c}\text { Gross cash value of } \\
\text { agricultural production (Rs) }\end{array}$ \\
\hline Average & 2.01 & 39,950 \\
Standard deviation & 1.46 & 26,736 \\
Minimum & 0.45 & 10,310 \\
Maximum & 5.7 & 130,440 \\
Range & 5.25 & 120,130 \\
\hline
\end{tabular}

Data source: Field survey, 1998 
Table 5. Correlation coefficient of land size with cash value of production and land use ratio

\begin{tabular}{lcc}
\hline \multicolumn{1}{c}{ Description } & \multicolumn{2}{c}{ Land type and size } \\
\cline { 2 - 3 } & Lowland (ha) & Upland (ha) \\
\hline Cash value of production (Rs.) & 0.88 & 0.61 \\
Land use ratio (\%) & 0.38 & 0.36 \\
\hline
\end{tabular}

Data source: Field survey, 1998

Table 6. Correlation coefficient of land size and fertilizer use with crop productivity

\begin{tabular}{lcr}
\hline \multicolumn{1}{c}{ Crop productivity (kg/ha) } & Land size (ha) & Fertilizer use (kg/ha) \\
\hline Maize & -0.45 & 0.66 \\
Paddy & 0.52 & 0.38 \\
Millet & -0.02 & -0.13 \\
Wheat & 0.59 & 0.70 \\
\hline
\end{tabular}

Data source: Field survey, 1998

relatively higher gross cash value of agricultural production and vice versa. Considerable difference was found both in the land size and gross cash value of agricultural production among the households (Table 4).

\section{Land type and size and its relationship with cash value of production and land use ratio}

Between the two types of land; low land and upland, correlation coefficient of land size and cash value of production is found higher in the low land than the upland (Table 5). This could be influenced by the factor such as; irrigation facility available in the low land contributing higher crop productivity, opportunity for growing additional crop, and price of commodity grown as rice is usually traded 2 to 3 times the price of any other grain. In the other hand, majority of food surplus households posses both low land and upland in larger area and low value of upland production from them alone might have effected this relation. In general, cash value of production per unit area of upland was found to be higher than the low land in the food deficit households (Lama and Tsuji $2000)$. Weak relationship (0.36) is found between the land size and land use ratio in both types of land.

\section{Land size and fertilizer use and its relation to crop productivity}

The correlation coefficient of land size and productivity of wheat and paddy (both low land crops) was found positive, although it is still weak (Table 6). However, there is a negative correlation between the land size and productivity of maize and millet (both upland crops). Maize being the major crop in the hills of Nepal, the negative relation with land size and productivity is not a good indication from the perspective of national thrust of increased agricultural production and food security.

Regarding the input use, positive correlation was found between the fertilizer use and productivity of wheat and maize. Wheat being a newly introduced crop and maize being the major crop in the hills of Nepal, the positive relation of fertilizer use with productivity provides a positive sign for developing strategies for food security in the hills. 
Table 7. Correlation coefficient of land size with household structure

\begin{tabular}{lc}
\hline \multicolumn{1}{c}{ Description } & Land size (ha) \\
\hline Family size (Number of person in family) & 0.69 \\
Major occupation of economically active members: & \\
Agriculture only (no. of person involved) & 0.38 \\
Non-farm work (no. of person involved) & -0.15 \\
Cash from non-farm source (Rs) & 0.13 \\
\hline
\end{tabular}

Data source: Field survey, 1998

\section{Household structure and its relation with land size}

There is positive relation between family size and the land size (Table 7). This is contributed by the fact that the most of the food surplus and balance households have a "joint family" system, where as the greater proportion of "nuclear family" in the case of food deficit households (lama \& Tsuji 1999). Farmers in the study area also reported that the proportion of nuclear family is generally increasing but much more so in the food deficit households as they can not sustain to feed from their own resources and tendency of sons to separate from the household when they marry is increasing. Kansakar (1995) states that between 1981 and 1991, the annual growth rate of households (1.78\%) in the eastern hill exceeds the growth of population (1.29\%) indicating a trend of increasing subdivision of households.

Weak relationship is found between the land size and number of people involved in agricultural activities. Number of person involved in non-farm work have a negative relation with land size giving an indication that much of the household with less land size are involved in non-farm work, as the land area they hold are not sufficient for living.

However, weak relation between the land size and cash from non-farm source indicates severe resource constraints among the small land holder: food deficit households. This relation again shows a "vicious circle of poverty" of less land size-less resources-low level of education-involve in non-skill and low paid job-resulting low income form non-farm sources-and finally in the depth of poverty.

\section{HOLDING OF LESS LAND SIZE BUT OBTAINING COMPARATIVELY HIGHER GROSS CASH VALUE OF AGRICULTURAL PRODUCTION}

From the Figure 3 and Table 8 , it is seen from the case (1) that, although A4 has a more cultivated land of 1.65 ha than the A3, but A3 draws more gross cash value of Rs. 13, 428 than the A4. Similar case of obtaining higher gross cash despite less land size is also found in case (2) (B2, B1) and case (3) (C4, D4). The point here to be examined is to find out as why some farm household have been able to draw more gross cash value despite having comparatively different in the size of cultivated land and what are the associated factors.

The result of comparative household analysis of case (1) between household A3 and A4 is presented here. These two cases are studied, as the land difference is nearly 2 hectares which is equivalent to the holding of 3-4 small landholder in the study area. Both the households were categorized as category A households (food surplus) during 


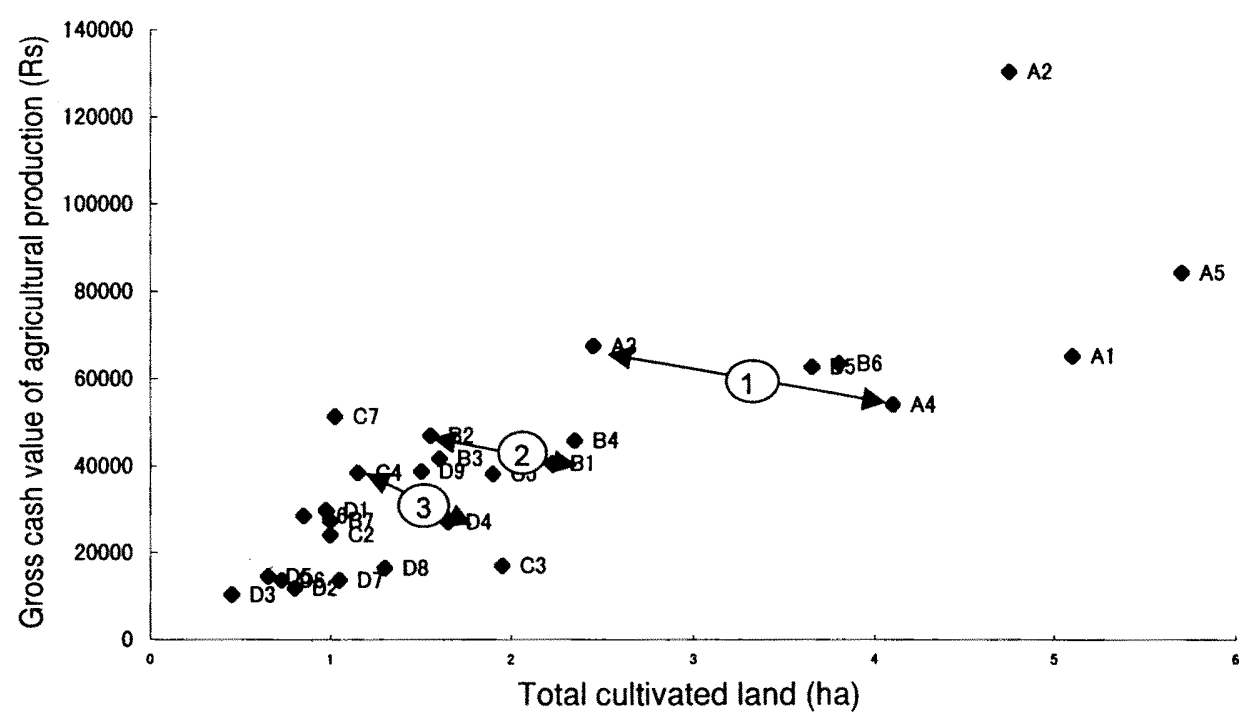

Fig. 3. Distribution of household with respect to land size (ha) and gross cash value of agricultural production in Rupees ( 1 Rs.=2 Yen)

Table 8. Three cases of less land size of $1.65,0.7$ and 0.5 hectare but obtaining comparatively higher gross cash value of agricultural production than their respective counterpart of bigger land size

\begin{tabular}{|c|c|c|c|c|c|}
\hline Cases & Farm household & $\begin{array}{l}\text { Cultivated land } \\
\text { size (ha) }\end{array}$ & $\begin{array}{l}\text { Gross cash } \\
\text { value of agri. } \\
\text { production (Rs) }\end{array}$ & $\begin{array}{l}\text { Difference in } \\
\text { land size (ha) }\end{array}$ & $\begin{array}{l}\text { Difference in } \\
\text { gross cash } \\
\text { (Rs.) }\end{array}$ \\
\hline \multirow[t]{2}{*}{ Case (1) } & A3 & 2.45 & 67,500 & $-\cdots$ & 13,428 \\
\hline & $\mathrm{A} 4$ & 4.1 & 54,072 & 1.65 & - \\
\hline \multirow[t]{2}{*}{ Case (2) } & $\mathrm{B} 2$ & 1.5 & 46,880 & - & 6,360 \\
\hline & $\mathrm{B} 1$ & 2.2 & 40,520 & 0.7 & - \\
\hline \multirow{2}{*}{ Case (3) } & $\mathrm{C} 4$ & 1.15 & 38,400 & - & 11,360 \\
\hline & D4 & 1.65 & 27,040 & 0.5 & - \\
\hline
\end{tabular}

Data source: Field survey, 1998

the farmer categorization exercise and there was no disparity in the source of cash value of agricultural production.

In order to examine the possible factor influencing the variation in gross cash value of agricultural production, following factors were examined between the households A3 and A4: 1) sources of gross cash value of agricultural production, 2) land type and their contribution, 3) cropping pattern and crop productivity, 4) Livestock holding and fertilizer use, 5) Household structure, educational attainment, major occupation of family members and its contribution to household cash, and finally 6) land holding and land use ratio.

These factors were considered on the basis of fact that the agricultural production in 
Table 9. Sources of gross cash value of agricultural production in Rs

\begin{tabular}{lrr}
\hline Sources of gross cash value of & \multicolumn{1}{c}{ A3 } & \multicolumn{1}{c}{ A4 } \\
agril. Production in Rupees & $(2.45$ ha $)$ & Rs. 25,650 \\
Cereal & Rs. 31,400 & 4,322 \\
Pulses & 6,020 & 6,000 \\
Potato & 1,080 & 11,000 \\
Fruits & 8,000 & 7,000 \\
Livestock & 21,000 & Rs. 54,072 \\
Total Rs. & Rs. 67,500 & \\
\hline
\end{tabular}

Data source: Field survey, 1998 (pulses also includes the cash value of mustard)

Table 10. Land type and their contribution to gross cash value

\begin{tabular}{lrr}
\hline \multicolumn{1}{c}{ Description } & A3 (2.45 ha) & A4 (4.1 ha) \\
\hline Low land (ha) & $1 \mathrm{ha}$ & $1.25 \mathrm{ha}$ \\
Cash value of low land production & $17,600 \mathrm{Rs}$ & $10,750 \mathrm{Rs}$ \\
Upland (ha) & $1.45 \mathrm{ha}$ & $2.25 \mathrm{ha}$ \\
Cash value of upland production & $20,900 \mathrm{Rs}$ & $25,222 \mathrm{Rs}$ \\
Fruit garden (ha) & - & $0.6 \mathrm{ha}$ \\
Cash from sale of fruit & $* 8,000 \mathrm{Rs}$ & $11,000 \mathrm{Rs}$ \\
\hline
\end{tabular}

Data source: Field survey, 1998 (*Does not have separate fruit garden, but fruit cultivated along with cereal crops in upland)

the hills of Nepal depends on the environment in which farmer works, and the way the household makes the combination and operation of the major production factors specially land and labor.

\section{Sources of gross cash value of agricultural production}

Both the households have five different sources that includes cereal, pulses, potato, livestock and fruits contributing to their gross cash value of agricultural production (Table 9). Despite less land size, A3 derive comparatively higher cash value from both cereal and pulses and three times more cash from the livestock sector. A4 relatively draws more cash value from fruit and potatoes production.

\section{Land type and their contribution to the gross cash value of agricultural production:}

A4 have advantage of more land area in all three types of land: i.e. upland, low land and fruit garden (Table 10). However, A3 despite having 0.25 ha less area of low land, still draws more cash value from low land. A4 have more upland area of 0.8 hectare and fruit garden, and also draws more cash value of Rs. 4300 and Rs. 3000 from upland and from fruit sale respectively than A3. However, A3 overcome this area disadvantage of upland and fruit garden by successfully applying inter-cropping of rain-fed upland crops with 250 fruit trees of orange planted in upland.

\section{Cropping pattern and productivity in the low land and upland}

Difference in cropping pattern was found in the low land between A3 and A4, as A3 cultivates 2 crops of paddy in half of their low land (Table 11). A4 do cultivates wheat after paddy harvest, the area covered is only small portion of land and much of the low 
Table 11. Cropping pattern of $A 3$ and $A 4$ in low land and upland with area allocated for each crop in percent, cash value of respective crop in Rupees and crop productivity in $\mathrm{kg} / \mathrm{ha}$

\begin{tabular}{|c|c|c|c|c|}
\hline Description & Land type a & nd crops & A3 (2.45 ha) & A4 (4.1 ha) \\
\hline \multirow{10}{*}{ Cropping pattern } & \multirow{3}{*}{\multicolumn{2}{|c|}{ Lowland }} & Rice-rice ( $50 \%$ of land area) & - \\
\hline & & & & Rice-wheat (12\%) \\
\hline & & & Rice-fallow (50\%) & Rice-fallow (88\%) \\
\hline & \multirow{7}{*}{\multicolumn{2}{|c|}{ Upland }} & Fruit trees & \\
\hline & & & Maize/millet ( $24 \%$ of area) & Maize/millet ( $9 \%$ of area) \\
\hline & & & Maize-pulses (55\%) & Maize-pulses (38\%) \\
\hline & & & Maize-mustard (7\%) & Maize-mustard (27\%) \\
\hline & & & Maize-potato (7\%) & Maize-potato (15\%) \\
\hline & & & Maize-vegetable (1\%) & Maize-vegetable $(3 \%)$ \\
\hline & & & Maize-fallow $(6 \%)$ & Maize-fallow ( $8 \%)$ \\
\hline Cash value of crop & (Lowland) & Rice & Rs. 17,000 & Rs. 10,000 \\
\hline \multirow[t]{7}{*}{ production in Rupees. } & & Wheat & 0 & 750 \\
\hline & (Upland) & Maize & Rs. 12,000 & Rs. 12,500 \\
\hline & & Millet & 1,800 & 2,400 \\
\hline & & Pulses & 4,920 & 2,892 \\
\hline & & Mustard & 1,100 & 1,430 \\
\hline & & Potato & 1,080 & 6,000 \\
\hline & (fruit trees) & Orange & 8,000 & - \\
\hline Crop productivity & & Rice & 1,431 & 1,162 \\
\hline \multirow[t]{4}{*}{$\mathrm{kg} / \mathrm{ha}$} & & Wheat & - & 1,000 \\
\hline & & Maize & 1,152 & 773 \\
\hline & & Millet & 714 & 1,248 \\
\hline & & Potato & 700 & 5,000 \\
\hline
\end{tabular}

Data source: Field survey, 1998

land remains fallow during winter. The location of paddy field at the low altitude of 1,120 meter and availability of small irrigation source to some of its paddy plots contributed A3 to have two crops of paddy. In other hand, the paddy field of A4 is located at the altitude of 1,560 meter where the two crops of paddy is not possible. Comparatively higher paddy productivity further helped A3 to obtain higher gross cash from low land.

Considerable difference was found on land use practices in the upland. Although, both adopt maize-based cropping pattern, A3 applies it inside the fruit trees by carefully managing the space available. Besides extra cash derived by planting fruit trees in upland, A3 also derives almost equal cash value of production from maize, pulses, millet and mustard with the exception of potato (Table 11). Obtaining almost equal cash value from cereal and pulses despite having 0.8 hectare less upland area is mainly contributed by higher maize productivity followed by increased crop ratio of pulses.

It was found from the above analysis that obtaining comparatively higher cash value of production despite having less land size is contributed by cash from livestock sector, intensive utilization of upland by carefully maintaining mixed cropping of fruit trees and maize-based cropping pattern, higher crop productivity of paddy and maize, followed by increase crop ratio of paddy and pulses. In order to examine these factors, again comparative analysis is made between these households on livestock number and fertilizer use, household structure and educational attainment and finally the land holding 
Table 12. Livestock holding and fertilizer use between $A 3$ and $A 4$

\begin{tabular}{|c|c|c|}
\hline Description & $\mathrm{A} 3(2.45 \mathrm{ha})$ & A4 (4.1 ha) \\
\hline \multicolumn{3}{|l|}{ Number of livestock holding: } \\
\hline Large (Cow, buffalo, oxen) & 9 & 5 \\
\hline Small (Goat, pig) & 25 & 12 \\
\hline Poultry & 40 & 4 \\
\hline \multicolumn{3}{|l|}{ Farm Yard Manure (FYM) } \\
\hline FYM produced in Metric ton & 20 & 5 \\
\hline \multicolumn{3}{|l|}{ Use of FYM (MT) for } \\
\hline Upland & $12.5 \mathrm{mt}$ applied for maize $(5.1 \mathrm{mt} / \mathrm{ha})$ & Applied all fym for maize ( $1.2 \mathrm{mt} / \mathrm{ha})$ \\
\hline Low land & Not applied & Not applied \\
\hline Fruit trees & $\begin{array}{l}\text { Applied } 7.5 \mathrm{mt} \text { of FYM with the rate } \\
\text { of } 25 \mathrm{~kg} / \text { tree. }\end{array}$ & - \\
\hline \multicolumn{3}{|c|}{ Use of chemical fertilizer (urea) in $\mathrm{kg} / \mathrm{ha}$} \\
\hline paddy & 20 (only for early rice) & 19 \\
\hline wheat & -(wheat is not cultivated) & 67 \\
\hline maize & 69 & 0 \\
\hline
\end{tabular}

Data source: Field survey, 1998

Table 13. Household structure, educational attainment, major occupation and total household cash value of $\mathrm{A} 3$ and $\mathrm{A} 4$

\begin{tabular}{|c|c|c|}
\hline Description & A3 (2.45 ha) & A4 (4.1 ha) \\
\hline Family size (Number of family members) & 8 & 7 \\
\hline $\begin{array}{l}\text { Economically active members (persons between } 16 \text { to } 60 \\
\text { years of age) in \% }\end{array}$ & 75 & 57 \\
\hline \multicolumn{3}{|l|}{ Educational status of family members in $\%$} \\
\hline lliterate & 12.5 & 14 \\
\hline Literate & 12.5 & 14 \\
\hline Primary level education & - & 43 \\
\hline Lower secondary level education & - & 28 \\
\hline Secondary level education & 50 & - \\
\hline College/university level education & 25 & - \\
\hline \multicolumn{3}{|l|}{ Major occupation of economically active members in \% } \\
\hline Agriculture only & 33 & 50 \\
\hline Full time non-farm job & 17 & 25 \\
\hline Student & 50 & 25 \\
\hline \multicolumn{3}{|l|}{ Household cash value in Rs. } \\
\hline Gross cash value of agricultural production & 67,500 & 54,072 \\
\hline Cash from non-farm job & 250,000 & 60,000 \\
\hline Total household cash value (agri + non - farm) & 317,000 & 114,072 \\
\hline
\end{tabular}

Data source: Field survey, 1998

and land use ratio.

\section{Livestock holding and fertilizer use}

Household A3 posses large number of livestock (both large and small) than the A4 (Table 12). Livestock are prime source of manure as farm yard manure (FYM) are made from its dung mixed with bedding material. Consequently, A3 produced 4 times more FYM then the A3 and accordingly applied more quantity of FYM in upland maize. Both households do not use FYM in the low land but applies equal amount of chemical fertilizer 
Table 14. Land holding (ha) and land use ratio (\%)

\begin{tabular}{|c|c|c|}
\hline Description & A3 (2.45 ha) & $\mathrm{A} 4$ (4.1 ha) \\
\hline (1) Total land holding in ha. & 2.45 & 5.9 \\
\hline (2) Rented out land in ha & - & 1.8 \\
\hline (3) Total cultivated land $(1-2)$ in ha & - & 4.1 \\
\hline Rented out land in $\%$ of total land holding & - & 30 \\
\hline (5) Form of land rent & - & Share cropping \\
\hline \multicolumn{3}{|l|}{ Land use ratio in $\%$ in } \\
\hline low land & 150 & 112 \\
\hline upland & $188+$ fruit cultivation & 184 \\
\hline
\end{tabular}

Data source: Field survey, 1998

for paddy crop. A4 do not use chemical fertilizer for maize crop with the impression that irregular use of chemical fertilizer in upland may destroy the soil property and productivity.

\section{Household structure, educational attainment, major occupation of family members and its contribution to household cash}

Both $\mathrm{A} 3$ and $\mathrm{A} 4$ have a joint family system and almost same family size (Table 13), however, A3 (75\%) has more economically active population than the A4 (57\%). Beside, 75 percent family members of A3 were well educated as they have an educational attainment of secondary and university level education compare to A4, where majority (71\%) had only primary or lower secondary education level. The education factors also made a difference in the major occupation of active members and also the cash derived from non-farm job. Consequently, A3 despite less land size, derive higher gross cash not only from agriculture, but from non-farm job too, contributing further difference in total household cash value than the A4.

\section{Land holding and land use ratio}

A4 (4.1 ha) besides having more cultivated land of 1.65 hectares than the A3 (2.45 ha), actually found to be holding 5.9 hectare of land suitable for agricultural operation (Table 14). Which means, A4 cultivates 4.1 hectares of land and remaining 30 percent of land (1.8 ha) is rented out on the share cropping basis; a privilege enjoy just by having more land area without putting any effort on agricultural operation. Holding of excess land may be the result that the land use ratio of A4 both in the low land and upland was comparatively lower than the A3 (Table 14).

\section{CONCLUSION}

Although, land is a major factor of production, its distribution was found extremely unequal among the household categories. Of the total land, 53 percent of land area is held by category A followed by 27 percent by category B, leaving only remaining 12 and 8 percent of land to category $\mathrm{C}$ and $\mathrm{D}$ respectively. Consequently, average land holding of the category $\mathrm{A}$ was found to be six times larger than the category $\mathrm{D}$ and five times than that of category $\mathrm{C}$ indicating a declining in holding from food surplus categories to the deficit categories. Interestingly, much of the land posses by category A were inherited land. Nearly half of the households of food deficit categories were found to be relying on 
rented in land from category A for agricultural operation and subsistence.

The result shows a positive relationship between the land size and the gross cash value of agricultural production which indicates that larger land holding tends to have relatively higher gross cash value and vice versa. Between the two land types; correlation coefficient of land size and production is found higher in the low land than the upland. There is negative relationship between the land size and productivity of both maize and millet. Maize and millet being the major hill and upland crops, the negative relation with land size and productivity gives a critical issues to be tackle in the near future for maintaining food security and eradicating poverty in the hills of Nepal. Positive but weak relationship was found between the land size and productivity of paddy and wheat; both low land crops. Weak relationship was found between the land size and land use ratio in both types of land; i.e. upland and lowland. Regarding the input use, positive correlation was found between the fertilizer use and productivity of maize and wheat.

Positive relationship was found between the land size and family size indicating a larger land holder consisting with larger family size. This is contributed by the family structure as most of the food surplus and balance households have a joint family system, whereas the greater proportion of nuclear family in the case of food deficit households. There is weak relation between the land size and number of economically active members engaged in agriculture. Negative relationship was found between the land size and number of family members engaged in non-farm job which shows that the majority of the small holder are involved in non-farm work for living; as the land area they hold is not sufficient for subsistence. However, weak relation found between the land size and cash from non-farm source indicates a severe resource constraint among the small land holders in terms of land and capital. This relation again shows a "Vicious circle of poverty" starting from less land size-less production and resources-inability to spend for education, low level of education-involve in non-skill and low paid job-resulting low income from non-farm sources-debt trap and finally in the depth of poverty.

Beside positive relation between the land size and gross cash value of agricultural production, there appears to be difference in gross cash value of agricultural production; (i) even within the same size of land and (ii) holding of less land but obtaining more gross cash value of agricultural production. An individual household analysis having less land size of 1.65 hectare but obtaining comparatively higher gross cash value than that of large land holder is carried out. The result shows that obtaining comparatively higher gross cash value of production despite having less land size is contributed by cash from the livestock sector, intensive utilization of upland by carefully managing mixed cropping of fruit trees and maize--based cropping pattern, higher crop productivity of paddy and maize followed by increase crop ratio of paddy and pulses. However, these same factors were found to be further influenced by the socio-economic characteristics of the households such as the possession of livestock number and fertilizer use, educational attainment of family member, and actual possession of land area.

\section{REFERENCES}

APROSC and JMA 1995 Nepal Agricultural Perspective Plan. Agricultural Project Service Center, Kathmandu and John Mellor Associates Inc, Washington D. C, pp. XVII

Carson, B. 1992 The Land, The Farmer and The Future: A Soil Fertility Management Strategy for Nepal. 
ICIMOD Occasional Paper No. 21, Kathmandu, Nepal, pp. 14-15

Dahal, K. M. 1993 Future of Nepalese Economy. Nepal Foundation for Advanced studies (NEFAS), PO Box 6154, Kathmandu, Nepal, pp. 3

Joshi, Y. R. et. al. 1993 Preliminary Surveys of Two Outreach Sites in the Koshi Hills: A Report on the "Wealth Ranking" Approach, Application and Preliminary Findings. PAC Working Paper No. 73, Pakhribas Agricultural Center, Dhankuta, Nepal

Kansakar, V. 1995 Household Analysis: Size, Composition and Headship Rates in the population monograph of Nepal, HMG/N National Planning Commission Secretariat, Central Bureau of Statistics, Kathmandu, Nepal

Lama, N. G. and Tsuji, M. 2000 Production Difference in the Same Size of Land and Associated Factors: A case study in the eastern hill of Nepal. Farm Management Seminar Report No. 1, Department of Agricultural and Resource Economics, Graduate School of Bioresource and Bioenvironmental Sciences, Kyushu University, pp. 113-126

Lama, N. G. and Tsuji, M. 1999 Understanding Farm Household from the Household Food Security Perspective: A case study in the eastern hill of Nepal. Japanese Journal of Farm Management, Vol. 37, No. 1, pp. 149-152

MOF, 2000 Economic Survey Fiscal Year 1999-2000. His Majesty's Government, Ministry of Finance, Kathmandu, Nepal

NESAC 1998 Nepal Human Development Report. Nepal South Asia Center, Post Box No. 8248, Tripureswar, Kathmandu, Nepal, pp. 117-118

Tiwari, B. M. 1990 Farm Size and Productivity in Nepalese Agriculture: A Case Study of Nawal Parasi District. Research Report Series Number 9, HMG Ministry of Agriculture-Winrock International, Policy Analysis in Agriculture and Related Resource Management, Kathmandu, pp. 1-2 